\title{
Student voice: What can we learn from twice-exceptional students about the teacher's role in enhancing or inhibiting academic self- concept
}

\author{
Geraldine Townend and Donna Pendergast, Griffith University
}

\begin{abstract}
Academic self-concept relates to students' perceptions of their academic accomplishments, and academic competence and expectations of academic success or failure. Academic self-concept has been identified as being critical for academic success in school as it underpins educational aspirations, academic interest, course selection, and achievement over time. Twice-exceptional students are intellectually gifted with a coexisting disability and hence present as a dual paradox for education systems, both in terms of being gifted and having a disability. The paradox of two, or one, or neither of the exceptionalities being visible in a child in school is due primarily to outward behaviours, lack of community knowledge, and challenges with identification (Vail, 1989). Despite over twenty years of empirical research on twice-exceptional students, the influences on academic self-concept remains virtually unexplored. This research investigates teachers' influences on the school experience of twice-exceptional students and how these influences shape academic self-concept. A case study research design includes both quantitative instrument data and interview data. Findings provide new understandings about teachers' influences on academic self-concept for twice-exceptional students. This research contributes to a gap in the field and leads to a better understanding that can be applied to policy and practice for gifted education.
\end{abstract}

Keywords: Academic self-concept, gifted education, twice-exceptional, teacher relationships, social interactions

Intellectually gifted students with a disability often known as twice-exceptional students - are among the most misunderstood students in our schools (Foley Nicpon, Allmon, Sieck \& Stinson, 2011). The premise that students can be twice exceptional is generally accepted in the field of gifted education (Assouline, Foley Nicpon \& Whiteman, 2010; Baum \& Owen, 2004; Baum, 1984; Brody \& Mills, 1997; Foley Nicpon, Assouline \& Colangelo, 2013; Neihart, 2008; Nielsen, 2002). Giftedness has numerous definitions (Renzulli \& Reis, 2002) and may include intellectual, creative, musical, sporting and other domains. This research focuses on the intellectual domain. Intellectual giftedness is frequently based on traditional intelligence testing (Litster \& Roberts, 2011) to indicate superior cognitive ability (Gagné, 2010, 1995; Renzulli \& Reis, 2002; Sternberg, 2000). For instance, IQs well above average have long been regarded as a classical feature of intellectual giftedness (Marland, 1972).

Twice-exceptional students typically experience challenges in education systems (Assouline et al., 2010). It is estimated by Barber and Mueller (2011) that up to one in five gifted students may also meet the criteria for twice-exceptionality, which is having a disability that affects learning and being gifted. Twice-exceptional students often go unnoticed or are only partially accommodated either due to the masking effect of one exceptionality concealing the other exceptionality or because there is no concrete understanding of how these dual effects manifest in a child (Foley Nicpon et al., 2011). Yet research (Rogers, 2011) affirms that twiceexceptional students must have both the giftedness supported and the disability accommodated in school in order to optimally address their learning needs. Notwithstanding over twenty years of empirical research with twice-exceptional students as the subjects, publications show that the influences on their academic self-concept - that is, perceptions about academic competence - remain virtually unexplored. These students are at a high risk of academic underachievement and this is likely to be linked to their academic self-concept, psychosocial well-being and educational achievement (Townend, Pendergast \& Garvis, 2014).

Academic self-concept plays a critical role in identity formation (Marsh \& Hau, 2003) and is considered to be important for academic success in school (Marsh \& Craven, 1997; Mendaglio, 2013; Xin \& Hao, 2003). It relates to students' 
understanding of their academic accomplishments and academic competence, expectations of academic success or failure, and academic self-beliefs (Marsh, 2011). Academic self-concept has been identified as being critical for academic success as it underpins educational aspirations (Davis, Rimm \& Siegle, 2011; Marsh \& Craven, 2000), academic interest (Marsh, Hau \& Craven, 2004; Marsh, 2011), course selection (Marsh \& Yeung, 1997a), achievement over time (Marsh \& Yeung, 1997b), and life success and satisfaction up to a decade after leaving school (Field, Sarver, \& Shaw, 2003; Skinner, 2003). Academic self-concept is comprised of several related perceptions, "competence, self-worth, interest, enjoyment, intentions, to name but a few" (Bong \& Skaalvik, 2003, p.29). A number of studies indicate that students with high academic self-concept enjoy comparatively higher teacher connection and higher academic achievement, and ultimately higher life satisfaction (Pekrun, Elliot, \& Maier, 2009; Pekrun \& Frese, 1992).

As there is limited literature specifically related to the academic self-concept for twiceexceptional students (Townend et al., 2014), an examination of the literature formed the basis of the study and revealed what we know about academic self-concept for gifted students, and academic self-concept for students with disability. This interface of findings for gifted students and students with disability prompts one to speculate on how the academic selfconcept in twice-exceptional students might manifest.

\section{Informing Literature}

An Australian study indicates that teachers have been provided with little or no knowledge and understanding of twice-exceptional students in Australia (Wormald, 2011). As a result, twiceexceptional students are often recognised for their disability, but not their gifts (Davis \& Rimm, 1998; Lovecky, 2004). This lack of understanding of students with twiceexceptionalities can lead to low academic achievement in school as twice-exceptional students are not only "waiting to fail, they are failing to flourish" (Assouline et al., 2010. p.103). The outcomes for twice-exceptional students have been long established in the literature to include academic underachievement, school drop out, and negative psychosocial issues as a result of, and including for example, depression and anxiety (Foley Nicpon et al., 2013; Neihart, 1999, 2008; Vespi \& Yewchuck, 1992). These outcomes are not surprising as the school environment creates a context for a variety of emotional experiences
- including influences as a result of interactions with teachers - which can influence learning (Lipnevich, MacCann, Bertling, Naemi, \& Roberts, 2012). The thesis of this research is that the influence of teachers on twice-exceptional students' academic self-concept determines their motivation, school connection, academic achievement, and, ultimately, life satisfaction (Pekrun et al., 2009; Pekrun \& Frese, 1992).

Research highlights a low general self-concept for twice-exceptional students (Assouline, 2011), and academic self-concept is a part of this general self-concept. Ahmed and Bruinsma (2006) adopted the self-concept model of Shavelson, Hubner and Stanton (1976), which defines self-concept as “a person's perception of himself [sic], formed through environmental experiences and significant others" (p. 554). It is argued that self-concept is the most important attribute for gifted children to recognise their potential (Feldhusen \& Hoover, 1986).

Coleman (2001) reports that twice-exceptional students have feelings of frustration in school due to the pressure to perform and the barriers to performance. If twice-exceptional students do not typically demonstrate levels of giftedness in the classroom with high levels of academic achievement, they are likely to disengage and some might present disruptive classroom behaviours, and an overall resistance to school possibly due to the difficulty in finding true or like-minded peers in the classroom context (Barber \& Meuller, 2011; Foley Nicpon et al., 2013; Neihart, 2008; VanTassel-Baska, Feng, Swanton, Qeck, \& Chandler, 2009).

Studies tend to agree that academic self-concept has a strong correlation with academic achievement (Ahmed \& Bruinsma, 2006; Pekrun et al., 2009; Pekrun \& Frese, 1992; Shavelson, Hubner \& Stanton, 1976). It reflects students' perceptions of specific and general academic achievements (Bahr \& Pendergast, 2007), and includes emotional reactions to academic domains (Lipnevich et al., 2012). Emotional reactions include enjoyment, anxiety, and are influenced by relationships with teachers (Goetz, Frenzel, Pekrun, Hall, \& Ludtke, 2007). Studies indicate that positive emotions in school predict positive outcomes (Fredrickson, 2001; Lipnevich et al., 2012; Seligman \& Csikszentmihalyi, 2000). Educators often have a false belief that academic accomplishments alone contribute to academic success, but academic self-concept also relates to emotional reactions to academic domains and academic experiences, including interactions with teachers, so that previous academic success is positively related to academic self-concept (Hampton \& Mason, 2003). 
Dole (2000) suggests that the single largest factor that appears to differentiate the twiceexceptional group from gifted students is a sense of inefficacy [sic] (or sense of incapability) in school, despite the creative potential of the twice-exceptional group. As a result of lack of understanding of, and a lack of identification in the education system, twice-exceptional students have lower self-concept, a sense of low capability, higher hypersensitivity, and higher emotional volatility (Dole \& Mueller, 2001). Twice-exceptional students are unseen by teachers and are underrepresented in gifted and enrichment programs (VanTassel-Baska, Johnson \& Avery, 2009).

A number of studies reveal that gifted students who are achieving can have comparatively high academic self-concept, gifted students who are not achieving have lower academic self-concept, and students with disability have low academic self-concept (Assouline, 2011; Barber \& Meuller, 2011; Baum \& Owen, 1988; Colangelo \& Assouline, 1995; Li, Shi, Zhao, Wang, Zhuang \& Mao, 2004; Litster \& Roberts, 2011; Reis \& Terry, 2000). The influences on academic self-concept are extensive and varied and some of the more commonly identified influences are now presented.

Assouline, Colangelo, Ihrig and Forstadt (2006) suggested that recognising the causal attributions of, for example, environment and identity formation, is useful for educators to understand motivation and achievement in the academic environment. Thus, understanding how identity is associated with being smart or good at something relates to a positive academic selfconcept in that area (Townend et al., 2014). However, negative outcomes might occur if experiences of failure are attributed to lack of ability and lead to lack of motivation, for example "[I]f I'm no good at it, why should I try?" (Dai, Moon \& Feldhusen, 1998; Dweck, 1986; Weiner, 1985). Assouline et al. (2006) suggested that realistic attributions for success are important as misattributions may lead to negative outcomes including underachievement. Assouline et al. (2006) identified that underachievers can be labelled as 'lazy' in lay terms and that such underachievement is often multi-faceted. Gilmore and Boulton-Lewis (2009) reported that in a study of 20 primary school students who had been labelled 'lazy' by their parents and teachers, 17 of these students (85\%) had an unidentified disability. The influence on students' identity and academic self-concept, whether gifted, twice-exceptional, with disability or labelled as 'lazy', can only be speculated upon but it is assumed that it will not be a positive influence on academic selfconcept. As twice-exceptional students have the traits of being gifted, are vulnerable to underachievement, and have a disability, it is likely that their academic self-concept will be influenced by these traits.

Further contributing factors to academic selfconcept include social and interactional influences through gestures or verbal and written responses from significant others - including parents, teachers, and peers. Students report their parents and teachers are an important influence on their academic and career choices (Hodkinson \& Sparkes, 1997; Knowles, 1998). The primary influence from significant others is in the form of social interaction and feedback. Verbal, gestural or written feedback, subtle or otherwise, can inform an individual of their social comparison and has been suggested to be effective and influential in all arenas including the academic (Niznikowski, 2013). McNeill (2007) investigated the significance of gesture, not only in social interaction, but also as an influence on cognitive activity. Gesture, McNeill claims, is an indispensable part of our self-communicative activities (2007). Gesture is not a substitute for verbal communication but a complement to it, thus, when we interact with others, gestural signals as well as verbal provide meaning in the interaction. Gesture influences social interaction in a reciprocal process between an individual and others (McNeill, 2007) and, as a result, influences both social activity and the internalisation of such activity within an individual through processes such as self-talk. In a study on self-talk, Burnett and Proctor (2002) noted that positive teacher statements - both verbal and gestural - indirectly led to positive self-talk and pro-social skills, which had a positive effect on academic self-concept. Craven, Marsh and Debus (1991) also report that teachers had a positive influence on self-concept through the enhancement of school relationships. Key researchers support the notion of significant others in context or environment and the influences by teachers on academic selfconcept have been implied in many studies (Kurtz-Costes, Rowley, Harris-Britt, \& Woods, 2008; Nota, Ferrari, Soresi, \& Wehmeyer, 2007; Shogren et al., 2007; Wehmeyer, Abery, Zhang, Ward, Willis, Hossain \& Walker, 2011).

Feedback provided by teachers regarding academic achievement is also considered to influence academic self-concept. Valentine, DuBois and Cooper (2004) found that enhancements in prior academic achievement led to improvements in subsequent academic self-concept and achievement. Other research supports the notion that academic self-concept is enhanced with positive feedback through increased academic achievement (Marsh \& Craven, 2006; Marsh \& O’Mara, 2008). Academic 
achievement levels can be influenced by teacher talk and teacher relationships (Bong \& Skaalvig, 2003). Previous academic success is positively related to high academic self-concept (Hampton \& Mason, 2003).

The literature reveals the gap in research associated with the unique aspects of academic self-concept of twice-exceptional students. Although the gifted are a diverse group, gifted and twice-exceptional students share common characteristics. These characteristics can also create social and emotional difficulties in school that undermine resilience (Reis \& Blacher, 2002). Some gifted and twice-exceptional students may feel detached or isolated, or have difficulty with self-regulation and this, therefore, highlights their unique socio-emotional needs (Barber \& Mueller, 2011; Dole, 2001; Reis, Neu \& Mcguire, 1995; Reis, 2007; Vespi \& Yewchuck, 1992).

When taken together, the literature reveals that high performing gifted students can have comparatively high academic self-concept and low performing gifted students and students with disability can have low academic self-concept (Assouline, 2011; Barber \& Mueller, 2011; Baum \& Owen, 1988; Reis et al., 2000). It would appear from the literature that twiceexceptional students have challenges, particularly the likelihood of underachievement, with the potential for low academic self-concept of both a gifted underperforming student and a student with disability (Assouline, 2011; Barber et al., 2011; Baum et al., 1988; Reis \& Terry, 2000).

\section{Purpose of this Study}

The aims of this study were to measure academic self-concept of twice-exceptional students, to explore their school experiences with teachers, and to explore the relationships between the two. To do this, an analysis of the academic selfconcept of three twice-exceptional students, utilising case study methodology and employing a multi-methods framework, was used. The invitation to encourage more qualitative research in the gifted field (VanTassel-Baska, 2006a, 2006b) has been heeded, and this research is aimed at enhancing the understanding of the complex phenomenon of twice-exceptional students. This contribution to the field aims to provide a platform for understanding phenomena using context-based, case-study methodology, and, although not generalisable, will contribute to informing a gap in the literature (Assouline, Foley Nicpon \& Doobay, 2009).

The case study site is an independent school in
Queensland, providing the milieu pertinent for this research in that it provides the situation in which academic self-concept is influenced. The self-perceptions of the participants' academic success are consequential in the formation of academic self-concept, and school is a key context for such opportunities for perceptions of success (Cross, 2013).

\section{Method}

Data were collected through the administration of standardised test instruments along with interviews conducted with each of the three participant students. Instrument data were analysed and interpreted using validated test parameters, and interview data were analysed using thematic content analysis with both hand coding and the Leximancer software program. The research aims were addressed though the collection and analysis of the data, as outlined in Table 1.

This research aims to provide new understanding about the influences of teacher relationships on academic self-concept for twice-exceptional students. The quantitative, psychometric instruments, already established and used for research in the gifted education field (e.g. Assouline et al., 2009), provided information about psychosocial perceptions, self-concepts and behaviour. Self-concept was measured using the $\mathrm{PH}-2$ (Piers-Harris Children's Self-Concept Scale $2^{\text {nd }}$ edition questionnaire). The $\mathrm{PH}-2$ (Piers \& Herzberg, 2002) is a self-report instrument for the assessment of self-concept in children and adolescents between the ages of seven and eighteen years old. The $\mathrm{PH}-2$ has been used extensively by researchers in the gifted and twice-exceptional fields for general self-concept in twice-exceptional students (e.g., Assouline et al., 2010; Olenchak, 1995; Tong \& Yewchuk, 1996; Yong \& McIntyre, 1991).

The BASC-2 (Behavioural Assessment for Children $2^{\text {nd }}$ edition) was then implemented as part of an assessment battery that indicates behavioural functioning and self-perceptions of children. Constructed by Kamphaus and Reynolds (2004), the BASC -2 has been used by researchers in the psychological, educational, and medical fields (Assouline et al., 2009; Nickerson \& Fishman, 2009; Rogers, 2010, Wolfe-Christensen, Mullins, Stinnet, Carpentier \& Fedele, 2009). It was designed to assist in diagnosis and classification of emotional and behavioural disorders of children at different stages of development. This instrument measures behavioural and emotional 
Table 1

How research aims are addressed by data sources and analysis

\begin{tabular}{|c|c|c|}
\hline Study Aims & Instrument & Analysis Tools \\
\hline $\begin{array}{l}\text { To measure academic self-concept in } \\
\text { twice-exceptional students. } \\
\text { To elicit the perceptions of school } \\
\text { experiences for twice-exceptional } \\
\text { students. } \\
\text { To investigate the relationship } \\
\text { between academic self-concept and } \\
\text { school experiences and cultural } \\
\text { context. } \\
\text { To investigate the relationship } \\
\text { between academic self-concept and } \\
\text { social interactions. }\end{array}$ & $\begin{array}{l}\text { Semi-structured interview } \\
- \text { one per student }-60 \\
\text { minutes. } \\
\text { BASC }-2^{*} \text { questionnaires. } \\
\text { PH-2** }\end{array}$ & $\begin{array}{l}\text { To characterise the participant } \\
\text { looking for similarities and } \\
\text { differences and using descriptive } \\
\text { statistics and thematic content } \\
\text { analysis. }\end{array}$ \\
\hline $\begin{array}{l}\text { To investigate how academic self- } \\
\text { concept manifests in social } \\
\text { interactions and behaviours in twice- } \\
\text { exceptional students. }\end{array}$ & $\begin{array}{l}\text { BASC-2 - student form. } \\
\text { BASC-2 - teacher form. } \\
\text { BASC-2 - parent form. } \\
\text { BASC-2 - } 2 \text { x classroom } \\
\text { observations in perceived } \\
\text { area of strength \& } \\
\text { weakness. }\end{array}$ & $\begin{array}{l}\text { Descriptive statistics to } \\
\text { characterise the participant } \\
\text { looking for similarities and } \\
\text { differences } \\
\text { Thematic content analysis of } \\
\text { classroom observations. }\end{array}$ \\
\hline $\begin{array}{l}\text { To find the perceptions of school } \\
\text { experiences for twice-exceptional } \\
\text { students. }\end{array}$ & $\begin{array}{l}\text { Semi-structured interview } \\
- \text { one per student }-60 \\
\text { minutes. } \\
\text { BASC-2 questionnaires. }\end{array}$ & Thematic content analysis \\
\hline $\begin{array}{l}\text { To find academic achievement } \\
\text { histories of twice-exceptional } \\
\text { students. }\end{array}$ & $\begin{array}{l}\text { BASC-2 achievement } \\
\text { history questionnaire with } \\
\text { parents. } \\
\text { School records } \\
\text { achievement history e.g. } \\
\text { standardised tests and } \\
\text { report grades. }\end{array}$ & $\begin{array}{l}\text { Thematic content analysis. } \\
\text { Notes to identify achievements }\end{array}$ \\
\hline $\begin{array}{l}\text { To measure academic self-concept in } \\
\text { twice-exceptional students }\end{array}$ & $\mathrm{PH} 2$ & $\begin{array}{l}\text { Descriptive statistics to indicate } \\
\text { themes. }\end{array}$ \\
\hline $\begin{array}{l}\text { To investigate the relationship } \\
\text { between academic self-concept and } \\
\text { school experiences. }\end{array}$ & $\begin{array}{l}\text { Semi-structured interview } \\
\text { with students }-60 \\
\text { minutes } \\
\text { BASC-2 and } \mathrm{PH} 2\end{array}$ & $\begin{array}{l}\text { Descriptive statistics to describe a } \\
\text { trend } \\
\text { Thematic content analysis of } \\
\text { interview transcript. }\end{array}$ \\
\hline $\begin{array}{l}\text { To investigate how academic self- } \\
\text { concept manifests in behaviours in } \\
\text { twice-exceptional students as a } \\
\text { possible indication for identifying } \\
\text { twice-exceptional students. }\end{array}$ & $\begin{array}{l}\text { BASC-2 - student form. } \\
\text { BASC-2 - teacher form. } \\
\text { BASC-2 - parent form. } \\
\text { BASC-2 - } 2 \text { x classroom } \\
\text { observations in perceived } \\
\text { area of strength \& } \\
\text { weakness. }\end{array}$ & $\begin{array}{l}\text { Descriptive statistics to indicate } \\
\text { themes or describe a trend. } \\
\text { Thematic content analysis of } \\
\text { classroom observations. }\end{array}$ \\
\hline
\end{tabular}

* Behavior Assessment System for Children, Second Edition

** Piers Harris Children's Self-Concept Scale, Second Edition

strengths and weaknesses. Gifted education literature recognises the importance of understanding how the giftedness impacts the disability and, conversely, how the disability impacts the giftedness (e.g., Assouline et al., 2009). When gifted students have co-occurring social difficulties, it is critical to determine if socialisation issues reflect an internal disability or whether the social isolation is environmentally based (Assouline et al., 2009). Insights into the influences of environment and socialization were highlighted by the BASC-2 and provided insights for academic self-concept. The data were sourced from the students', teachers' and parents' perspectives. Table 2 shows the forms within the instruments that were used and by whom.

The interview questions were designed to collect data related to four key areas and are shown in Table 3. First, general, and current perceptions about school and academic achievement were explored. Second, are the ways in which the student perceives success or otherwise. Third, are how the school experiences impacted selfperceptions and academic motivation and achievement. Fourth, are how other people 
affect self-perceptions and school experiences. These four areas directly addressed the research aims through the exploration of self-perspective as the student participants told their stories and shared their experiences. A pilot study with small group interviews of twice-exceptional students - who did not participate in the main study - parents, and teachers enabled the questions to be reviewed in advance of the research. Feedback from the groups ensured that the questions were clear, the meanings precise and that the questions would optimally explore the research questions. Supporting the research in the sociocultural framework, the interviews were conducted in the school environment, enabling the participants to create responses in a familiar setting (Neuman, 2000). The questions were sensitive to gender, class, and cultural contexts. The interviews lasted 60 minutes.

The three student participants were assigned pseudonyms. Andrew (Year 11, senior school), Ben (Year 8, middle school), and Chris (Year 4, primary school) were all identified as gifted by clinical psychologists using the Wechsler Intelligence Scale for Children Fourth Edition (WISC IV) or Stanford Binet Fifth Edition (SB 5). Their full scale IQs varied between 109 (with the highest subscale at 126 and the lowest at 92) and 131 (with the highest subscale at 131 and the lowest at 119). All three participants had a specialist report detailing central auditory processing disorder (CAPD). Chris was also diagnosed with Asperger's Syndrome and Ben with a hearing impairment.

The three participants completed two self-report measures: the BASC-2 and the $\mathrm{PH}-2$, which were analysed alongside the specialist reports from school records. All of the questionnaires gave psychometric data in quantitative format. The BASC -2 and $\mathrm{PH} 2$ indicated the traits and perceptions of all participants to provide background information in order to enhance the qualitative data collection (Creswell, 2009). The aim of the instrument data was to assess behaviour and self-perceptions of participants (BASC-2) and their self-concepts (PH2).

Semi-structured interviews were then conducted with the participants. As multiple sources of data are used for case studies the interview questions were devised in light of both the questionnaire data and the review of the literature including: general and current perceptions about school and academic achievement, the ways in which the participants perceived success, how the school experiences impacted on self-perceptions and academic motivation and achievement, and finally, how other people affect self-perceptions and school experiences.

A coding paradigm similar to one used by Reis et al. (1997, 2000) and devised by Strauss (1987) and Strauss and Corbin $(1990,1998)$ was used for the interview analyses. The Leximancer computer program was then used to further explore the thematic coding of the data. Leximancer is an automated system for content analysis of text. The system claims to transform lexical co-occurrence information from natural language to semantic patterns in an unsupervised manner (Smith \& Humphreys, 2006). Smith and Humphreys (2006) defend the face validity, stability, reproducibility, correlative validity, and functional validity of Leximancer and the program supported the hand coding.

Table $2 \quad$ BASC-2 and PH2 Instrument Forms

\begin{tabular}{|c|c|c|}
\hline Name of Form & Person completing & Information provided \\
\hline $\mathrm{PH}^{*}$ & Participant & Measures self-concepts \\
\hline $\begin{array}{lll}\text { BASC-2**: Self-Report } & \text { of } \\
\text { Personality (SRP) } & \\
\end{array}$ & Participant & $\begin{array}{l}\begin{array}{l}\text { Measures emotions and self- } \\
\text { perceptions }\end{array} \\
\end{array}$ \\
\hline $\begin{array}{lll}\text { BASC-2: } & \text { Parent Rating } & \text { Scale } \\
\text { (PRS) } & & \\
\end{array}$ & Parent & $\begin{array}{l}\text { Measures child's } \\
\text { behaviours }\end{array}$ \\
\hline $\begin{array}{l}\text { BASC-2: Teacher Rating Scale } \\
\text { (TRS) }\end{array}$ & Teacher & $\begin{array}{l}\text { Measures child's } \\
\text { behaviours }\end{array}$ \\
\hline $\begin{array}{ll}\text { BASC-2: } & \text { Structured } \\
\text { Developmental History (SDH) }\end{array}$ & Parent & $\begin{array}{l}\text { Detailed descriptions of child's } \\
\text { developmental history }\end{array}$ \\
\hline $\begin{array}{l}\text { BASC-2: Student Observation } \\
\text { System }(\mathrm{SOS})^{* * *}\end{array}$ & Researcher & $\begin{array}{l}\text { A form for recording and classifying } \\
\text { directly observed } \\
\text { behaviour }\end{array}$ \\
\hline
\end{tabular}

* Piers-Harris Children's self-concept scale - second edition

** Behavior Assessment System for Children- Second Edition

*** BASC-2 SOS - The BASC-2 student observation system used to observe the behaviours in two classroom environments - the least favourite subject and the favourite subject. 


\begin{tabular}{|c|c|c|c|}
\hline Purpose & Relevant questions & $\begin{array}{l}\text { Data collected } \\
\text { included }\end{array}$ & $\begin{array}{l}\text { Research question } \\
\text { addressed }\end{array}$ \\
\hline $\begin{array}{l}\text { General and current } \\
\text { perceptions about } \\
\text { school and academic } \\
\text { achievement }\end{array}$ & $\begin{array}{l}\text { Tell me how you feel } \\
\text { about school and how } \\
\text { well you feel you are } \\
\text { doing? }\end{array}$ & $\begin{array}{l}\text { Attitudes and beliefs to } \\
\text { support questionnaire } \\
\text { data about school, self- } \\
\text { perceptions and } \\
\text { academic self-concept }\end{array}$ & $\begin{array}{l}\text { How do social practices } \\
\text { and contexts that } \\
\text { influence the } \\
\text { development of } \\
\text { academic self-concept }\end{array}$ \\
\hline $\begin{array}{l}\text { Ways in which the } \\
\text { student perceives } \\
\text { success or otherwise }\end{array}$ & $\begin{array}{l}\text { What is it about } \\
\text { success, or otherwise, } \\
\text { that are valued by you? } \\
\text { Is success important for } \\
\text { you? In what areas and } \\
\text { how so? }\end{array}$ & $\begin{array}{l}\text { Underling values and } \\
\text { motivation for school } \\
\text { and schoolwork. } \\
\text { Perceptions of what is } \\
\text { valued on a personal } \\
\text { level and how this } \\
\text { might translate to } \\
\text { academic self-concept. }\end{array}$ & $\begin{array}{l}\text { How do social } \\
\text { interactions and social } \\
\text { practices and contexts } \\
\text { influence academic } \\
\text { self-concept. }\end{array}$ \\
\hline $\begin{array}{l}\text { History within school } \\
\text { and how it impacted } \\
\text { self-perceptions and } \\
\text { academic motivation } \\
\text { and achievement }\end{array}$ & $\begin{array}{l}\text { What are your } \\
\text { experiences in school } \\
\text { since you started in } \\
\text { Prep? Have they } \\
\text { changed? How so? } \\
\text { Can you give me } \\
\text { examples about what } \\
\text { you feel have supported } \\
\text { you, or otherwise, the } \\
\text { most? }\end{array}$ & $\begin{array}{l}\text { Perceptions of lived } \\
\text { experiences in practice. } \\
\text { Perceptions of how } \\
\text { school context values } \\
\text { certain traits and how } \\
\text { these are nurtured (or } \\
\text { otherwise). } \\
\text { Perceptions of social } \\
\text { acceptance in the } \\
\text { context of the school. }\end{array}$ & $\begin{array}{l}\text { How do social } \\
\text { interactions and social } \\
\text { practices and contexts } \\
\text { influence academic } \\
\text { self-concept. }\end{array}$ \\
\hline $\begin{array}{l}\text { How other people } \\
\text { affect the self- } \\
\text { perceptions and school } \\
\text { experience. }\end{array}$ & $\begin{array}{l}\text { Do you feel valued in } \\
\text { school? } \\
\text { Do relationships with } \\
\text { other people in school } \\
\text { influence the way you } \\
\text { feel about school or } \\
\text { your schoolwork? How } \\
\text { so? }\end{array}$ & $\begin{array}{l}\text { Perceptions of what are } \\
\text { valued within the } \\
\text { school organisation and } \\
\text { context and how this } \\
\text { translates into practice. } \\
\text { Details of how } \\
\text { relationships with } \\
\text { parents, teachers and } \\
\text { peers inform self- } \\
\text { perception and } \\
\text { academic self-concept. }\end{array}$ & $\begin{array}{l}\text { How do social practices } \\
\text { and contexts that } \\
\text { influence the } \\
\text { development of } \\
\text { academic self-concept }\end{array}$ \\
\hline
\end{tabular}

\section{Findings and Discussion}

All three student participants' received grades in the above average range in the infant school years (Years F-2), which then dropped into the below average range in the primary school years (Years 3-7). For Andrew and Ben who had moved into the senior school, their school achievement grades gradually increased from the start of Year 8 and both were performing with well above average grades at the time of the research. $\mathrm{PH} 2$ data indicated that all participants have low selfconcept in most of the subscales including the intellectual self-concept subscale.

All three participants perceived teachers as highly important in their lives and that interactions with teachers were essential for their sense of well-being and achievement at school. The relationship with their teacher and the subsequent feedback from teachers were important for engagement with their academic work. As Andrew notes, "I chose the subjects I did because I enjoy them, because I get good grades, and I feel more interested in what we're learning and the teacher is approachable" (Andrew, Individual Interview, November 11, 2011). The BASC-2 data indicated a low (in the clinical range) attitude to teachers in the primary years for all participants, which improved in the middle years for Andrew and Ben, and was well above average for Andrew in Year 11. Such negative experiences in primary school are exemplified in the following quote "[I]n primary school you only had one teacher and that is what you were stuck with, whether you liked it or not" (Ben). Andrew concurred about primary school and the impact of having one classroom teacher:

If [the teachers] don't like what they are teaching, it passes to the students and they will go down.... And if they don't like you that's it! And in the early years if that happens you have just that teacher for the year and you are stuffed" (Andrew, Individual Interview, November 11, 2011).

Still in the primary years, Chris stated, “I don't 
like being at school, I hate being alone, the teachers don't get me" (Chris, Individual Interview, November 21, 2011).

The BASC-2 showed that all participants had perceptions in the clinical range of atypicality, anxiety, social relationships, sense of inadequacy, self-esteem, and self-reliance. All participants scored low self-concepts across the $\mathrm{PH}-2$ instrument, including intellectual selfconcept. This result was interesting as Andrew and Ben had reversed their academic underachievement and were receiving above average (mainly $A$ grades) in academic achievement grades.

Table 4 gives an example of the summary of Andrew's PH-2 results. The results indicated that he has low self-concept (presented as percentiles) in all subscales except for behaviour [he evaluated himself as well behaved but acknowledged that he had a few difficulties with his conduct (Piers \& Herzberg, 2002)] and popularity - he perceived that he was average in social functioning, perceived popularity, ability to make friends, and feelings of inclusion (Piers \& Herzberg, 2002).

The participants all reported that, in the context of the school, teachers have the highest influence. Likewise, all participants reported feeling on the periphery of the school community as a result of the feedback and social interactions with their teachers. The data implied that the more positive feedback they received from teachers, the stronger was their sense of belonging and success, which positively influenced sense-of-self in the school context and academic self-concept.

Academic achievement for all participants related to perceived feedback for academic work. This feedback included, for example, teacher-talk and gestures, academic grades, and achievement tests - all of which have a direct influence on academic self-concept (Liem et al., 2013.) Andrew gave an example of how teacher feedback in the form of grades had a strong influence on him, "[Y]ou feel so awesome. That is what happened with one of my geography tests - I wasn't sure if I'd done good but I was fairly confident and when I saw I got an A I was, inside, so invincible because I had done so well"

(Andrew, Individual Interview, November 11,
2011). Additionally, the data implied that teachers are the most influential with regards to academic achievement including their enthusiasm, feedback, and teacher-talk as Ben indicated, "I just never really overall liked the teacher because he just builds up, builds up and then snaps and like screams at someone who never like gets into trouble or anything. I don't really like Religion because of this".

In interviews, participants also implied that feeling at an intellectual disadvantage led to their lack of participation in the classroom, "I know I will look stupid if I say anything” (Chris, Individual Interview, November 21, 2011). The BASC-2 student observation system used to observe the behaviours in two classroom environments (the favourite and least favourite subjects) illustrated that all participants were quiet and isolated (socially and/or physically) by their own choice from their classroom peers. They were either studious or disengaged but their behaviour was not disruptive. They were all quiet and did not participate in classroom discussions. Andrew reinforced this, "I feel overall that I am a pretty bright kid but sometimes not over super-intelligent like kids in this school are. Like some of the kids do things I would never have thought of" (Andrew, Individual Interview, November 11, 2011). However, positive relationships with teachers have contributed to positive learning experiences and have lessened their feelings of intellectual disadvantage as highlighted by Ben:

$[M] r$ T was a good teacher. He would not make you repeat easy stuff but allow you to skip and move on. He would make sure you were ok with important stuff so you wouldn't get smashed on the test . . . I couldn't have done it without him". (Ben, Individual Interview, November 18, 2011)

Coleman's (2001) notion that twice-exceptional students have feelings of frustration due to the pressure to perform academically and experience barriers to academic performance, leading to social difficulties and strained teacher relationships, are seen in the data. The participants all presented with low self-concepts $(\mathrm{PH} 2)$, and clinical range scores for emotional and behavioural disorders (BASC-2) in the school context.

Table 4

PH2 summary of results for Andrew

\begin{tabular}{llllllll}
\hline \multirow{2}{*}{ School yr } & \multicolumn{9}{l}{ Percentile } & \multicolumn{1}{l}{} \\
\cline { 2 - 8 } & Total & BEH & INT & PHY & FRE & POP & HAP \\
\hline 11 & 31 & 46 & 12 & 16 & 14 & 50 & 24 \\
\hline
\end{tabular}

* BEH is behavioural adjustment scale; INT is intellectual scale; PHY is physical appearance and attributes scale; FRE is freedom from anxiety scale; POP is popularity scale; and HAP is the happiness and satisfaction scale. 
Data, both instrument and interview, implied social difficulties with feelings of isolation and poor interpersonal relations that manifested in high levels of anxiety and perceptions of atypicality - all of which were supported by BASC -2 and could lead to the lowering of many aspects of self-concept, including academic selfconcept (Swiaeks, 2001).

For these participants, psychosocial well-being improved when they perceived support from their teachers, and when they were identified as gifted and their learning disabilities were supported. For Andrew and Ben, the change in their connection with their teachers and their school was pivotal around their identification as being gifted, their commencement at secondary school, and their improved grades. The data supported the claim that, as a result of lack of understanding and identification of twiceexceptional students in the education system, twice-exceptional students have lower selfconcept, higher hypersensitivity, and higher emotional liability (Dole \& Mueller, 2001); all participants perceived enhanced connection to school after identification and subsequent support by teachers.

The findings of Barber and Mueller (2011) and Reis and Renzulli (2004) showed that twiceexceptional students believed that they were at an intellectual disadvantage in the classroom and avoided opportunities to demonstrate their talent (Barber \& Mueller, 2011). As the perception of being different drives behaviours (Reis \& Renzulli, 2004; Rimm, 2006), the BASC-2 student observation (in the classroom) showed that the participants all remained very quiet in the classroom, not verbally participating, as they felt that they would show lack of ability. All participants stated or implied that this pattern became deeply entrenched in their early primary years. The participants did not exhibit disruptive classroom behaviours, but the data implied that there was disengagement, particularly when they did not connect with the teacher or the subject.

The participants revealed similar negative school experiences that Reis et al. (1997) uncovered in a study on twice-exceptional university students. All participants recalled or inferred negative school experiences, which included critical and hostile feedback, primarily from teachers; the feedback reported by Reis et al. (1997) ranged from direct, verbal feedback, to subtle, inferred body language, and gestures, thus reinforcing the social sensitivity that gifted students could demonstrate. All three participants reported that, when they felt supported by teachers, they are reminded of their potential to excel and they achieved more highly and their academic self- concept was enhanced. The data pointed to teacher feedback as being important for motivation in class, for example:

I wasn't getting very good grades and that and I felt I was going into a hole and was digging it deeper. But it just takes one small good thing to happen - and you get real motivation out of it - and it takes you out of the hole and you work to get things better and you feel better. I then got an ' $A$ ' grade it was uphill from there." (Andrew, Individual Interview, November 11, 2011)

Both Ben and Chris discussed the positive response and motivation resulting from positive teacher feedback, which led to positive self-talk and higher academic self-concept.

Craven and colleagues (1991) also identified that teachers have a positive influence on selfconcept through the enhancement of the school relationships. Andrew and Ben stated that relationships with teachers were instrumental in creating positive learning experiences. Positive relationships might be intertwined with how the talk of significant others impacts causal attributions, the foundations of which are embedded early in the skill experience. Assouline et al. (2006) suggested that recognising causal attributions can assist educators to understand motivation in the academic environment; a strong identity of being smart or good at something relates to a positive academic self-concept in that area, a notion revealed by the data, for example, "....when it comes to selfworth, if the teachers say you can do something, you think 'yeah - I can do that' and it makes you feel more able to do it" (Ben, Individual Interview, November 18, 2011).

In interviews, the participants pointed to positive teacher feedback, through verbal and gestural interactions, which lead to positive feelings - supported by the literature (Burnett et al., 2002) - and positive effects on academic self-concept. For all participants, attitudes to school were very low in the primary years as they suggested an intense dislike of school due to their relationship with the teachers. However, for Andrew and Ben, Year 8 and beyond have been positive experiences at school as a result of positive interactions with teachers, as is evident in the statement "[M]y teachers are awesome now . . . it's not what you might think in the early years, they are real easy to talk to and I feel much better around them compared to primary school when I felt pointless and stupid" (Andrew, Individual Interview, November 11, 2011). Connection with the teachers appeared to be important for the participants to feel valued and connected. Chris stated, “I don't like school, 
I hate being alone and the teachers don't get me" (Chris, Individual Interview, November 21, 2011), which indicated his sense of isolation due to lack of connection with his teachers.

Teacher feedback for academic work in the form of achievement grades is also important for the participants for their academic self-concept. The interview data of all three participants indicated that the grades they received are important and are positively correlated with their enjoyment of a subject, and positively correlated with their connection to the teacher. Having missed out by one ' $A$ ' grade from being on the 'Scholars' List', Ben felt disappointed and judged himself to be a low performer despite his high results for the first time in school. Andrew echoed this sentiment when discussing his subject choices and grades when he stated, "I chose the subjects I did because . . . I get good grades, so I feel more interested in the learning and I can compete with my classmates" (Andrew, Individual Interview, November 11, 2011).

The data supported the notion that academic achievement levels, and academic self-concept, could be influenced by teacher-talk, and school relationships (Bong et al., 2003; Liem, Marsh, Martin, Mclnerney \& Yeung, 2013). Ben suggested that enjoyment was enhanced by achievement "I get high marks in the subjects I enjoy. If I got low grades I probably wouldn't enjoy them" (Ben). All participants discussed teacher talk and teacher relationships, for example, Chris's view that ". . . having Asperger's or being gifted makes things harder I think, the teachers don't really get it" (Chris, Individual Interview, November 21, 2011). Andrew's similar recollection of teacher-talk and relationships with school was highlighted by "if you are doing good my teacher would be happy and would let you know it . . . and it makes you feel good".

All participants suggested that attending gifted classes, in addition to compensatory support for learning disabilities, enhanced academic achievement. Both Andrew and Ben reported that enjoyment of school has increased since being identified as gifted, particularly since commencing senior school when their grades also improved, for example, "I know I am doing OK because I'm in the smart classes at school" (Ben, Individual Interview, November 18, 2011). For Andrew and Ben, it would appear that recognition and teacher-talk initially influenced academic achievement, then academic success influenced academic self-concept (Hampton \& Mason, 2003). Participants suggested that the gifted classes are a supported and positive experience, as highlighted by Andrew, "I barely ever feel inadequate since I started gifted classes because, for me, it was such an easy place to come to and just connect with heaps of people" (Andrew, Individual Interview, November 11,2011$)$. Ben supported this notion and said "[T] he highlight of my primary school was when I got into the gifted classes" (Ben, Individual Interview, November 18, 2011). Thus the data supported the recommendations that a supportive environment is essential for gifted children to flourish (Dai \& Rinn, 2008; Little, 2012; Wendell, 1976). Their teachers and school support programs provided support mechanisms that enhanced the supportive environment for these participants. However, they suggested that the primary school experience of support is variable due to different teachers, different understandings, late identification, and lack of coherent programs. The support mechanisms reported by the participants included strong relationships with teachers, discreet support of the learning disabilities, interaction and learning opportunities with gifted peers, use of assistive technology, and learning self-advocacy and learning strategies.

As academic self-concept relates to students' perceptions of their academic accomplishments, academic competence, expectations of academic success or failure, and academic self-beliefs (Marsh, 2011), the data implied that academic achievement for these participants is underpinned by academic self-concept. Thus, in alignment with the literature, the data in this study revealed that teachers intrinsically influenced academic self-concept. In addition, the data supported the literature (Bong \& Skaalvig, 2003; Kurtz-Costes, Rowley, HarrisBritt, \& Woods, 2008; Marsh \& Craven, 2006; Marsh \& O'Mara, 2008; Nota, Ferrari, Soresi, \& Wehmeyer, 2007; Shogren et al., 2007; Wehmeyer, Abery, Zhang, Ward, Willis, Hossain \& Walker, 2011) that gifted and twiceexceptional students have experienced both positive and negative teacher relationships, which in turn has influenced their level of engagement with school and their academic selfconcept.

Although not generalizable due to the small cohort, the findings present similarities between all three case study participants that are worthy of attention as they are as distinctive as they are complex and novel. The similarities fell into two general areas: the psychosocial presentations of each participant, and their reported school experiences.

The psychosocial profiles of the three participants revealed that there are similarities between them in that they experienced intense emotions and they experienced feeling conflicted. The instrument data concurred with the findings of Assouline et al. (2009) in that the 
participants had scales in the at-risk range for social stress and interpersonal relationships. It might be that, due to a perceived lack of supportive teacher relationships in primary school, the participants have experienced interpersonal difficulty, which manifested in stress and dislike of school, and contributed to low academic self-concept.

The second area is the participants' school experiences. They all revealed experiencing a sense of 'difference' in school; and while they all wanted to fit in, at the same time they also desired to stand out. The three participants experienced similar emotions and attitudes towards school at similar ages and the data suggests similar insights in terms of their academic self-concept. All participants experienced negative school experiences with teachers, mainly in primary school due to school practices and the educational foci such as: a focus on handwriting and reading rather than on ideas and innovation; perceptions of difficult interactions with teachers; perceived 'threats' of having to repeat a year or attend special needs classes, and; detentions for lying that they prepared for the test when 'clearly' the test achievement indicated otherwise. The three participants have been accused of being lazy in their earlier years and told that, if they worked harder, they would achieve. The resultant influence on their self-talk led to low academic self-concept in primary school.

Measures taken in school can enable twiceexceptional students access to gifted programs. Intervention at school needs to be individualised: it is rare for a twice-exceptional student to meet a 'true peer' as so many variables are in play. Focusing only on areas requiring support in the early years might lead to lowered academic selfconcept and a lowered acceptance of intellectual challenge. In short, it is important to match a student's academic needs to the school curriculum, alongside remediation for their disability, access to programs that enhance their area of strength, and teacher interactions - all of which support the development of positive academic self-concept.

\section{Recommendations for further research}

In many ways these recommendations resemble those that might be made for all students. However what this study draws out is the assertion that teachers must be trained to identify and subsequently support twiceexceptional students. There are three recommendations for further research emanating from this study:

1. Investigate and make explicit accessible methods that enhance the identification of twice-exceptional students in schools.

2. Systemise the counselling needs of twiceexceptional students including how to effectively address psychosocial needs of twice-exceptional students.

3. Provide systematic professional development for teachers, employing optimal pedagogical approaches, to inform and enable practice and policy.

Optimally, further research should inform policymakers and result in legislation that provides for the spectrum of diversity found amongst school students, particularly twiceexceptional students, including the giftedness, to be enshrined in law. Twice-exceptional students can thrive in environments when they are explicitly taught effective compensation strategies for their learning disabilities. This research converges with the literature in recommending that twice-exceptional students need specialised programs for their areas of strength as well as remediation for their areas of disability.

\section{Conclusion}

The importance of the academic self-concept of students, both in school and beyond, has long been acknowledged in published research as an important predictor for academic success and life satisfaction. However, there has been no published research reporting on the academic self-concept of twice-exceptional students. This study makes a unique contribution to the field by providing insight into this phenomenon. This research has found that positive interactions with teachers are instrumental in the formation of academic self-concept for twice-exceptional students alongside identification, psychosocial support and environmental adjustments. This research converges with and furthers the literature in recommending that twiceexceptional students need specialised programs to enhance their areas of strength as well as remediation and in-school adjustments to address their areas of disability.

\section{References}

Ahmed, W., \& Bruinsma, M. (2006). A structural model of self-concept, autonomous motivation and academic performance in cross-cultural perspective. Electronic Journal of Research in Educational Psychology, 4(3), 551-576.

Assouline, S. G. (2011). Twice-exceptionality: What educators need to know to optimise the learning experience of twice-exceptional students. Sydney, Australia: GERRIC.

Assouline, S. G., Colangelo, N., Ihrig, D., \& Forstadt, L. (2006). Attributional choices for academic 
success and failure by intellectually gifted students. Gifted Child Quarterly, 50(4), 283-297.

Assouline, S. G., Foley Nicpon, M., \& Whiteman, C. (2009). Cognitive and psychosocial characteristics of gifted students with written language disability. Gifted Child Quarterly, 20(10), 14.

Assouline, S. G., Foley Nicpon, M., \& Doobay, A. (2009). Profoundly gifted girls and ASD spectrum disorder: A psychometric case study comparison. Gifted Child Quarterly, 53(2), 89-105.

Assouline, S. G., Foley Nicpon, M., \& Whiteman, C. (2010). Cognitive and psychosocial characteristics of gifted students with specific learning disabilities. Gifted Child Quarterly, 54, 102-115.

Barber, C., \& Mueller, C. T. (2011). Social and self perceptions of adolescents identified as gifted, learning disabled, and twice-exceptional. Roeper Review, 33(2), 109-120. doi:10.1080/02783193.2011.554158.

Bahr, N., \& Pendergast, D. (2007). The millennial adolescent. Melbourne, Australia: ACER.

Baum, S. M. (1984). Meeting the needs of learning disabled gifted students. Roeper Review, 7, 16-19.

Baum, S. M., \& Owen, S. V. (1988). High ability/learning disabled students: How are they different? Gifted Child Quarterly, 32(2), 321-326.

Baum, S. M., Owen, S. V., \& Dixon, J. (1991). To be gifted and learning disabled: From identification to practical intervention strategies. Melbourne, Australia: Hawker Brownlow Education.

Baum, S. M., \& Owen, S. V. (2004). To be gifted and learning disabled: Strategies for helping bright students with disability, $A D H D$, and more. Mansfield Center, CT: Creative Learning Press

Bong, M., \& Skaalvik, E. M. (2003). Academic selfconcept and self-efficacy: How different are they really? Educational Psychology Review, 15(1), 1-40.

Brody, L. E., \& Mills, C. J. (1997). Gifted children with learning disabilities: A review of the issues. Journal of Learning Disabilities, 30, 282-296.

Burnett, P. C., \& Proctor, M. (2002). Elementary school students' learner self-concept, academic self-concepts and approaches to learning. Educational Psychology in Practice, 18(4), 325-333.

Craven, R. G., Marsh, H. W., \& Debus, R. L. (1991). Effects of internally focused feedback and attributional feedback on enhancement of academic self-concept. Journal of Educational Psychology, 83(1), 377-392.

Colangelo, N., \& Assouline, S. G. (1995). Self-concept of gifted students: Patterns by self- concept domain, grade level, and gender. In M. S. Katzko \& F. J. Monks (Eds.), Nurturing talent: Individual needs and social ability (pp. 66-74). Assen, The Netherlands: Van Gorcum.

Coleman, M. R. (2001). Surviving or thriving? Gifted Child Today, 24(3), 56-64.

Creswell, J. W. (2009). Educational Research: Planning, conducting, and evaluating quantitative and qualitative research. New Jersey: Pearson Education Inc.

Cross, T. L. (2013). Suicide among gifted children and adolescents. Waco, Texas: Prufrock Press Inc.

Dai, D. Y. (2004). How universal is the big fish little pond effect? American Psychologist, 59, 267-268.

Dai, D. Y., Moon, S. M., \& Feldhusen, J. F. (1998). Achievement motivation and gifted students: A social cognitive perspective. Educational Psychologist, 33(2/3), 45-63.
Dai, D. Y., \& Rinn, A. N. (2008). The big-fish-littlepond-effect: What do we know and where do we go from here? Educational Psychological Review, 20, 283-317.

Davis, G., \& Rimm, S. B. (1998). Education of the gifted and talented (4th ed.). Boston, MA: Allyn \& Bacon.

Davis, G. A., Rimm, S. B., \& Siegle, D. (2011). Education of the gifted and talented (6th ed.). Boston, MA: Pearson.

Dole, S. (2000). The implications of the risk and resilience literature for gifted students with learning disabilities. Roeper Review, 23(2), 91-96.

Dole, S. \& Mueller, C.T. (2001). Reconciling contradictions: Identity formation in individuals with giftedness and learning disabilities. Journal for the Education of the Gifted, 25, 103-137.

Dweck, C. S. (1986). Motivational processes affecting learning. American Psychologist, 41, 1040-1048.

Feldhusen, J. \& Hoover, S. (1986), A conception of giftedness: Intelligence and self concept. Roeper Review, 8(3), 140-143.

Field, S., Sarver, M. D., \& Shaw, S. F. (2003). Selfdetermination: A key to success in postsecondary education for students with learning disabilities. Remedial and Special Education, 24(6) 339-349.

Foley Nicpon, M., Allmon, A., Sieck, B., \& Stinson, R. D. (2011). Empirical investigation of twiceexceptionality: Where have we been and where are we going? Gifted Child Quarterly, 55, 3-17. doi:10.1177/0016986210382575

Foley Nicpon, M., Assouline, S. G., \& Colangleo, N. (2013). Twice-exceptional learners: Who needs to know what? Gifted Child Quarterly, 57(3), 169180.

Frederickson, B. L. (2001). The role of positive emotions in positive psychology: The broaden-andbuild theory of positive emotions. American Psychologist, 56(3), 218-226. doi: 210.2110237/21000213-0266X.256.213.218.

Gagné, F. (1995). From giftedness to talent: A developmental model and its impact on the language of the field. Roeper Review, 18(2), 103111.

Gagné, F. (2010). Guest speaker series. Francoys Gagné and the DMGT 2.0. Brisbane, Australia: Independent Schools Queensland.

Gilmore, L., \& Boulton-Lewis, G. (2009). Just try harder and you will shine: A study of 20 lazy students. Australian Journal of Guidance and Counselling, 19(2), 95-103.

Goetz, T., Frenzel, A. C., Pekrun, R., Hall, N. C., \& Ludtke, O. (2007). Between-and-within-domain relations of students' academic emotions. Journal of Educational Psychology, 99, 715-733.

Hampton, N. Z., \& Mason, E. (2003). Learning disabilities, gender, self-efficacy, and academic achievement in high school students. Journal of School Psychology, 41(2), 101-112.

Hodkinson, P., \& Sparkes, A. (1997). Careership: A sociological theory of career decision-making. British Journal of Sociology of Education, 18(1), 29-44.

Kamphaus, R. W., \& Reynolds, C. R. (2011). Bacademic self-concept ${ }^{\mathrm{TM}}-2$

Behavioral and Emotional Screening System (BASC2 BESS).

Knowles, S. (1998). Effects of the components of parent involvement on children's educational and 
occupational aspirations (Unpublished doctoral dissertation). Alfred University, Alfred, NY.

Kurtz-Costes, B., Rowley, S. J., Harris-Britt, A., \& Woods, T. A. (2008). Gender stereotypes about mathematics and science and self-perceptions of ability in late childhood and early adolescence. Merrill-Palmer Quarterly, 54, 386-409.

Li, Y., Shi, J., Zhao, D., Wang, Z., Zhuang, J., \& Mao, L. (2004). The difference of nonintellectual factors between gifted and normal children. Chinese Mental Health Journal, 18, 561-563, 568.

Liem, G. A. D., Marsh, H. W., Martin, A. J., Mclnerney, A. M., \& Yeung, D. S. (2013). The big-fish-littlepond-effect and a national policy of within-school ability streaming: Alternative frames of reference. American Educational Research Journal, 50, 326370.

Lipnevich, A. A., MacCann, C., Bertling, J. P., Naemi, B., \& Roberts, R. D. (2012). Emotional reactions toward school situations: relationships with academic outcomes. Journal of Psychosocial Assessment, 30, 387-401.

Litster, K., \& Roberts, J. (2011). The self-concepts and perceived competencies of gifted and non-gifted students: A meta-analysis. Journal of Research in Special Educational Needs, 11(2), 130-140.

Little, C. A. (2012). Curriculum as motivation for gifted students. Psychology in the Schools, 49(7), 695-705.

Liu, W. C., \& Wang, C. K. J (2008). Home environment and classroom climate: An investigation of their relation to students' academic self-concept in a streamed setting. Current Psychology, 24(7), 242256.

Lovecky, D. V. (1992). Exploring social and emotional aspects of giftedness in children. Roeper Review, 15(1), 18-25.

Marland, S. P. (1972). Education for the gifted and talented: Report to the U.S. Congress of the United States by the US Commissioner for Education. Washington, DC: U.S. Government Printing Office.

Marsh, H. W. (2011). Academic self-concept and academic achievement: Relations and causal ordering. British Journal of Educational Psychology, 81(1), 59-77.

Marsh, H. W., \& Craven, R. (1997). Academic selfconcept: Beyond the dustbowl. In G. D. Phye (Ed.), Handbook of classroom assessment: Learning, achieving, and adjustment (pp. 131-198). Orlando, FL: Academic Press.

Marsh, H. W., \& Craven, R. (2000). The pivotal role of frames of reference in academic self-concept formation: The "big-fish-little-pond" effect. Paper presented at the Inaugural Self-Concept Enhancement and Learning Facilitation (SELF) Research Centre International Conference, Sydney, Australia.

Marsh, H. W., \& Craven, R. (2006). Reciprocal effects of self-concept and performance from a multidimensional perspective: Beyond seductive pleasure and unidimensional perspectives. Perspectives on Psychological Science, 1, 133-163.

Marsh, H. W., \& Hau, K. T. (2003). Big-fish-little-pond effect on academic self-concept: A cross- cultural (26 country) test of the negative effects of academically selective schools. The American Psychologist, 58(5), 364-376.
Marsh, H. W., Hau, K. T., \& Craven, R. (2004). The big-fish-little-pond-effect stands up to scrutiny. American Psychologist, 59(4), 269-271.

Marsh, H. W., \& O'Mara, A. (2008). Reciprocal effects between academic self-concept, achievement, and attainment over seven adolescent years: Unidimensional and multidimensional perspectives of self-concept. Personality and Social Psychology Bulletin, 34, 542-552.

Marsh, H. W., \& Yeung, A. S. (1997a). Coursework selection: Relations to academic self-concept and achievement. American Educational Research Journal, 34(4), 691-720.

Marsh, H. W., \& Yeung, A. S. (1997b). Causal effects of academic self-concept on academic achievement: Structural equation models of longitudinal data. Journal of Educational Psychology, 89, 41-54.

McNeill, D. (2007). Gesture and thought. Language in Society, 36(5), 764-768. DOI: $10.1017 /$ S0047404507070704

Mendaglio, S. (2013). Gifted students transition to university. Gifted Education International, 29(3), 3-12.

Neihart, M. (1999). The impact of giftedness on psychological well-being: What does the empirical literature say? Gifted Child Quarterly, 22(1), 1017.

Neihart, M. (2000). Gifted children with Asperger's syndrome. Gifted Child Quarterly, 44, 222-240.

Neihart, M. (2008). Identifying and providing services to twice-exceptional children. In S. I. Pfeiffer (Ed.), Handbook of giftedness in children: Psychoeducational theory, research and best practices (pp. 115-137). New York: NY: Springer.

Nielsen, M. E. (2002). Gifted students with learning disabilities: Recommendations for identification and programming. Exceptionality, 10, 93-111.

Neilson, G. R., \& McNally, J. (2013). The negative influence of significant others on high academic achieving school pupils' choice of nursing as a career. Nurse Education Today, 33(3), 205-209.

Nickerson, A. B., \& Fishman, C. (2009). Convergent and divergent validity of the Devereux student strengths assessment. School Psychology Quarterly, 24(1), 48-59. DOI: 10.1037/a0015147

Niznikowski, T. (2013). The effectiveness of different types of verbal feedback on learning complex movement tasks. Human Movement, 14(2), 148153.

Nota, L., Ferrari, L., Soresi, S., \& Wehmeyer, M. L. (2007). Self-determination, social abilities, and the quality of life of people with intellectual disabilities. Journal of Intellectual Disability Research, 51, 850-865.

Olenchak, F. R. (1995). Effects of enrichment on gifted/learning-disabled students. Journal for the Education of the Gifted, 18, 385-399.

Pekrun, R., Elliot, A. J., \& Maier, M. A. (2009). Achievement goals and achievement emotions: Testing a model of their joint relations with academic performance. Journal of Educational Psychology, 101(1), 115-135. doi:10.1037/a0013383

Pekrun, R., \& Frese, M. (1992). Emotions at work and achievement. In C. L. Cooper \& I. T. Robertson (Eds.), International review of industrial and organizational psychology (Vol. 7, pp. 153-200). Chichester, England: Wiley. 
Piers, E. V., \& Herzberg, D. S. (2002). Piers-Harris Children's Self-Concept Scale (2nd ed.). Los Angeles, CA: Western Psychological Services.

Reis, S. M., \& Blacher, J. (2002). Twice-exceptional: Learning disabled and gifted. The Exceptional Parent, 32(9), 5.

Reis, S. M. (2007). No child left bored. School Administrator, 64(2), 22-26.

Reis, S. M., Neu, T. W., \& McGuire, J. M. (1995). Talents in two places: Case studies of high ability students with learning disabilities who have achieved. Storrs, CT: The National Research Centre on the Gifted and Talented.

Reis, S., M., \& Terry, W. N. (2000). Compensation strategies used by high-ability students with learning disabilities who succeed in college. Gifted Child Quarterly, 44(2), 123.

Reis, S. M., Neu, T. W., \& McGuire, J. M. (1997). Case studies of high-ability students with learning disabilities who have achieved. Exceptional Children, 63, 463-479.

Reis, S. M., \& Renzuli, J. S. (2004). Current research on the social and emotional development of gifted and talented students: Good news and future possibilities. Psychology in the Schools, 41(1) 119129.

Renzulli, J. S., \& Reis, S. M. (2002). What is schoolwide enrichment? Gifted Child Today, 25(4), 18-25.

Rimm, S. (2006). Growing up too fast and gifted. Parenting for High Potential, 6, 23-31.

Rimm, S., Gilman, B., \& Silverman, L. (2008). Nontraditional applications of traditional testing. In J. L. VanTassel-Baska (Ed.), Alternative assessments with gifted and talented students (pp. 175-202). Waco, TX: Prufrock Press.

Rogers, K. B. (2010). Thinking Smart about twice exceptional learners: steps for finding them and strategies for catering to them appropriately [Presentation]. Minneapolis, MN USA: University of St. Thomas, College of Applied Professional Studies.

Rogers, K. B. (2011). Thinking smart about twiceexceptional learners: Steps for finding them and strategies for catering to them appropriately. In C. Wormald \& W. Vialle (Eds.), Dual exceptionality (pp. 57-71). Wollongong, Australia: Australian Association for the Education of the Gifted and Talented.

Seligman, M. E. P., \& Csikszentmihalyi, M. (2000). Positive psychology: An introduction. American Psychologist, 55, 5-14.

Seligman, M. E. P., Ernst, R. M., Gillham, J., Reivich, G., \& Linkins, M. (2009). Positive education: Positive psychology and classroom interventions. Oxford Review of Education, 35(3), 293-311. doi:10.1080/03054980902934563.

Shavelson, R. J., Hubner, J., \& Stanton, G. C. (1976). Self-concept: Validation of construct interpretations. Review of Educational Research, 46, 407-441.

Shogren, K., Wehmeyer, M. L., Palmer, S. B., Soukup, J. H., Little, T. D., Garner, N., \& Lawrence, M. (2007). Examining individual and ecological predictors of the self-determination of students with disabilities. Exceptional Children, 73, 488509.

Skinner, E., Edge, K., Altman, J., \& Sherwood, H. (2003). Searching for the structure of coping: A review and critique of category systems for classifying ways of coping. Psychological Bulletin, 129, 216-269.

Smith, A. E., \& Humphries, M. S. (2006). Evaluation of unsupervised semantic mapping of natural language with Leximancer concept mapping. Behavior Research Methods, 38(2), 262-279.

Sternberg, R. J. (2000). The concept of intelligence. In R. J. Sternberg (Ed.), Handbook of intelligence (pp. 3-15). Cambridge, England: Cambridge University Press.

Strauss, A. L. (1987). Qualitative analysis for social scientists. New York, NY: Cambridge University Press.

Strauss, A. L., \& Corbin, J. M. (1990). Basics of qualitative research: Grounded theory, procedures, and techniques. Thousand Oaks, CA: Sage.

Strauss, A. L., \& Corbin, J. M. (1998). Basics of qualitative research: Techniques and procedures for developing grounded theory. Thousand Oaks, CA: Sage.

Tong, J., \& Yewchuk, C. (1996). Self-concept and sexrole orientation in gifted high school students. Gifted Child Quarterly, 40, 15-23.

Townend, G., Pendergast, D., \& Garvis, S. (2014). Academic self-concept in twice-exceptional students: What the literature tells us. TalentEd, 28(12), 56-71.

Valentine, J. C., DuBois, D. L., \& Cooper, H. (2004). The relation between self-beliefs and academic achievement: A meta-analytic review. Educational Psychologist, 39, 111-133.

VanTassel-Baska, J. (2006a). NAGC symposium: A report card on the state of research in the field of gifted education. Gifted Child Quarterly, 50(4), 339.

Van Tassel-Baska, J. (2006b). A content analysis of evaluation findings across 20 gifted programs: A clarion call for enhanced gifted program development. Gifted Child Quarterly, 50(3), 199215, 273.

VanTassel-Baska, J., Feng, A. X., Swanton, J. D., Qeck, C., \& Chandler, K. (2009). Academic and affective profiles of low-income minority, and twice-exceptional gifted learners: The role of gifted program membership in enhancing self. Journal of Advanced Academics, 20(4), 702-739.

Van Tassel-Baska, J., Johnson, D., \& Avery, L.D. (2009). Using Performance Tasks in the Identification of Economically Disadvantaged and Minority Gifted Learners: Findings From Project STAR. Gifted Child Quarterly, 46(2), 110-123. DOI: 001698620204600204

VanTassel-Baska, J., Johnson, D. T., Hughes, C. E., \& Boyce, L. N. (1996). A study of language arts curriculum effectiveness with gifted learners. Journal for the Education of the Gifted, 19(4), 461-480.

Vespi, L., \& Yewchuk, C. (1992). A phenomenologial study of the social/emotional characteristics of gifted learning disabled children. Journal for the Education of the Gifted, 16, 55-72.

Wehmeyer, M. L., Abery, B. H., Zhang, D., Ward, K., Willis, D., Hossain, W. A., \& Walker, H. M. (2011). Personal self-determination and moderating variables that impact efforts to promote selfdetermination. Exceptionality, 19, 19-30. 
Weiner, B. (1985). An attributional theory of achievement motivation and emotion. Psychological Review, 92, 548-573.

Wendell, S. (1996). The rejected body: Feminist philosophical reflections on disability. New York, NY: Routledge.

Wormald, C. (2011). What knowledge exists in NSW schools of students with learning difficulties who are also academically gifted? Australasian Journal of Gifted Education, 20(2), 5-9.
Xin, S., \& Hao, C. (2003). Review of the relations between children's self-concept and school achievement. Beifang Luncong, 5, 121-125.

Yong, F. L., \& Mclntyre, J. D. (1991). Comparison of self-concepts of students identified as gifted and regular students. Perceptual and Motor Skills, 73(443-446).

\section{Contact Details}

Geraldine Townend, PhD

Griffith University

Email: g.townend@griffith.edu.au

\section{Biographical details}

Dr Geraldine Townend is working in research work and lecturing at Griffith University in Queensland. Geraldine has expertise in the psychosocial influences on gifted children, particularly twice-exceptional children. Geraldine's recent research explored the various influences on academic self-concept in twiceexceptional students, the findings of which indicate that teacher relationships, peer relationships, social comparison theory, academic achievement and psychological centrality are some of the key contributors. Part of that research is presented in this paper.

Professor Donna Pendergast is Dean and Head of the School of Education and Professional Studies at Griffith University and has conducted a number of national research projects of significance including "Beyond the Middle", which investigated literacy and numeracy in middle schooling; and "Lifelong Learning and Middle Schooling". She has completed an evaluation of the Education Queensland Virtual Schooling Service and is often employed as a consultant to review school reform initiatives. Donna has several books published of relevance to contemporary teacher work and is highly sought after as a speaker on the topic of the MilGen and teaching, and has completed several intergenerational studies in content areas. Donna is a member of the IFHE Executive, Chairperson of the IFHE Think Tank Committee, and Editor of the International Journal of Home Economics. Donna has expertise in effective teaching and learning for middle years students, including those who are twice-exceptional. 